\title{
On the Link Between Managerial Attributes and Firm Access to Formal Credit in Myanmar
}

\author{
Henrik Hansen ${ }^{1}$ (D) $\cdot$ John Rand ${ }^{1} \cdot$ Finn Tarp $^{1} \cdot$ Neda Trifkovic ${ }^{1}$
}

Accepted: 7 October 2020 / Published online: 12 January 2021

(c) UNU-WIDER 2021, corrected publication 2021

\begin{abstract}
Using a survey of enterprises in Myanmar, we examine demand for formal credit and the extent to which firms are self-constrained by not applying for credit or if they apply and are constrained by bank's rejections. We have information about firm managers' managerial capacity and risk attitude. We use this to test if the allocation of loanable funds is systematically associated with the attributes. We find that these attributes are positively associated with firm performance and the probability of both having credit demand and applying for credit. On the supply side we find no discernible links to the traits once we control for self-constraint in applying for credit. Thus, the traits improve credit access through a higher likelihood of applying for credit not a higher probability of being granted credit when applying. We suggest to improve the allocation of credit by incentivizing banks to utilize information about managers' business capacity.
\end{abstract}

\section{Resumé}

À l'aide d'une enquête sur les entreprises au Myanmar, nous étudions la demande de prêt bancaire et examinons dans quelle mesure les entreprises se restreignent ellesmêmes en ne faisant pas de demande de prêt ou bien, lorsqu'elles font une demande, dans quelle mesure elles sont restreintes par le refus des banques. Nous disposons

This study is a part of the UNU-WIDER project 'Towards inclusive development in Myanmar'www. wider.unu.edu/project/towards-inclusive-development-myanmar.

Henrik Hansen

Henrik.Hansen@econ.ku.dk

John Rand

John.Rand@econ.ku.dk

Finn Tarp

Finn.Tarp@econ.ku.dk

Neda Trifkovic

Neda.Trifkovic@econ.ku.dk

1 Department of Economics, University of Copenhagen, Øster Farimagsgade 5, Building 26,

1353 Copenhagen, Denmark 
d'informations sur la capacité de gestion des dirigeants d'entreprise et sur leur attitude face au risque. Nous utilisons ces données pour tester si l'allocation des prêts est systématiquement associée à ces caractéristiques managériales. Nous constatons que ces caractéristiques sont positivement associées à la performance de l'e ntreprise et à la probabilité à la fois d'avoir besoin d'un prêt et de faire une demande de prêt. Du côté de l'offre, nous ne trouvons aucun lien avéré avec ces caractéristiques une fois que nous contrôlons l'auto restriction en matière de demande de prêt. Ainsi, ces caractéristiques managériales améliorent l'accès au crédit car elles sont liées à une probabilité plus importante de faire une demande de prêt mais non pas d'obtenir un crédit en cas de demande. Nous suggérons d'améliorer l'allocation de prêts en incitant les banques à utiliser les informations sur la capacité des dirigeants à gérer leur entreprise.

\section{Introduction}

There is broad consensus about the many and varied obstacles to entry, survival and growth of micro, small and medium enterprises (SMEs) and access to credit systematically appears as one of the most important constraints for SME growth (Ayyagari et al. 2008). As a result, banking sector reforms have consistently been advocated by the World Bank and credit programmes have been popular interventions by governments and donors for decades. Moreover, with the increasing focus on blended finance in development assistance, many donors now consider support to private banks in the form of loan guarantees to be an increasingly attractive instrument for SME development. However, the development impact of both micro-lending to enterprises and guarantee schemes to banks is somewhat smaller than hoped for (Banerjee et al. 2015; Cowan et al. 2015; Quinn and Woodruff 2019). One obvious reason being that SME performance is extremely heterogeneous, whereby the average treatment effect may well be low. In this situation, being able to select and support the firms with the best growth potential (picking winners) is crucial. Although this is a formidable task, entrepreneurial abilities and other traits of firm owners and managers have been shown to be useful predictors. Specifically, de Mel et al. (2008) find that high-ability owners have large marginal returns on capital, while Fafchamps and Woodruff (2017) and McKenzie and Sansone (2017) find that business management ability can predict firm growth.

Related to this literature, we examine the associations between firm level outcomes in the form of sales, profits, investment decisions and product innovation and the entrepreneurial attributes of the owner/manager in Myanmar. ${ }^{1}$ But our main contribution is to disentangle the impact of entrepreneurial attributes on formal credit demand and credit constraints. We start from the approach first formulated by

\footnotetext{
1 In $77 \%$ of the firm interviews the respondent was the owner of the firm. However, as the owner is also the manager of the firm in almost all cases when they are respondents we will denote the respondent simply as the manager rather than as the owner/manager throughout.
} 
Bigsten et al. (2003) and distinguish between firms with and without credit demand. Clearly, firms that apply for a loan have credit demand. But several firms that do not apply for a loan actually have credit demand as well. For example, some firms do not apply for a loan because application procedures are too complex or because the (perceived) collateral requirements are unattainable. Such firms are interesting because they are credit constrained by self-restriction. Thus, we extend the credit demand/ constrained analysis of Bigsten et al. (2003) and keep track of four types of firms: (i) firms with no credit demand, (ii) firms with credit demand that are credit constrained by self-restriction, (iii) firms with credit demand that are credit constrained by the formal banks and (iv) firms with credit demand that are not constrained. We examine the characteristics of the four groups of firms and assess the associations with the entrepreneurial attributes. Our analysis is based on the Myanmar Enterprise Monitoring System (MEMS), a nationally representative SME survey, which in addition to the standard data about firm size and performance has information about both credit demand, credit access and entrepreneurial attributes in the form of managerial capacity and risk attitudes.

Our results confirm the positive association between entrepreneurial abilities and firm performance found in other countries in that sales and profits as well as the propensity to invest and/or innovate are significantly, and substantially, associated with managerial capacity and willingness to take risk. For the allocation of formal credit, we show that firms with better managers are more likely to have credit demand and they are also more likely to apply for credit, but the probability of being granted credit, once they apply, is not affected by their managerial capabilities.

Since formal bank decisions to provide credit to SMEs seem to have no systematic association with the managers' attributes (conditional on demand and actually applying) it appears that formal banks in Myanmar use quite limited information about firm managers in their assessment of loan applications. Thus, our findings suggest that the Government of Myanmar and foreign donors in their support of the banking sector should promote the use of assessments of owner and manager managerial attributes when allocating guaranteed loans among SMEs. Along the same lines of reasoning, business training programmes for managers of SMEs should be accompanied by training programmes for credit providers, assuming the aim is to maximize the growth potential of the SME sector.

\section{Background}

\section{Enterprise Access to Finance in Myanmar}

The formal financial sector in Myanmar has historically been highly restricted and it remains among the most regulated in the world. Following the general elections in 2010, a reform process has begun, which includes financial liberalization (Win 2018). Even though there have been improvements, especially under the 2016 Myanmar Financial Institutions Law, the financial sector continues to be one of the most underdeveloped in the ASEAN region (Chassat and Forster 2016; Schellhase 
and Sun 2017). In the 2018 Doing Business report (World Bank 2018) Myanmar ranked among the lowest in Asia by all indicators in the 'Getting Credit' section. Fixed interest rate spreads, strict collateral requirements and complex application procedures in combination with financial illiteracy and low quality of loan applications, as well as liquidity problems of banks, are listed as the most crucial constraints to financial and SME development.

Myanmar has four dominant state-owned banks. ${ }^{2}$ However, in recent years their dominance has declined. Their share of total banking assets decreased from $67 \%$ in 2013 to $46 \%$ in 2016, while their share of total domestic banking deposits decreased from $50 \%$ to $36 \%$, and the share of total domestic banking loans fell from $43 \%$ to 18\% (Chassat and Forster 2016). Deposit and loan activities are now also undertaken by Myanmar's 24 domestic private banks and 13 foreign banks. The domestic private bank sector is dominated by three major banks ${ }^{3}$ Together, these three banks hold about two-thirds of all loans and deposits and more than half of all bank branches in the country (Schellhase and Sun 2017). Lack of competition in the formal financial sector therefore remains a serious concern (Chassat and Forster 2016; Schellhase and Sun 2017; Waldschmidt and Marga 2016).

Despite a large increase in banking assets between 2012 and 2016 [120\% according to Schellhase and Sun (2017)], access to finance is generally considered as the major constraint to business development by enterprises, banks, and politicians in Myanmar (World Bank 2015). Fifty-four percent of Myanmar's SMEs report that they have unmet financial needs (Bernhardt et al. 2017) and the majority of loanable funds is handed out to a segment of large borrowers with high amounts of collateral, concentrated in urban areas (Annamalai 2017). As a result, the share of SMEs involved with the formal financial system is very limited (Annamalai 2017; World Bank 2015). Many SMEs therefore depend on other sources of finance.

In the city of Yangon it is estimated that only $14 \%$ of the SMEs obtained a formal loan, while 23\% got an informal loan in the period 2012-2014 (Kapteyn and Wah 2016). The latter comes with considerable costs as interest rates on informal loans are on average $39 \%$ per year compared to $8.5-13 \%$ for formal loans. Moreover, loan amounts offered in the informal sector are on average only one-third of those offered by formal financial institutions (Kapteyn and Wah 2016). Consequently, a significant proportion of SMEs in Yangon rely on retained earnings for financing working capital and new investments. Kapteyn and Wah (2016) find that $89 \%$ of the SMEs use personal or family savings as start-up capital, and 52\% use them for business operations and expansion.

Several reasons for the lack of loanable funds available to SMEs have been highlighted. One problem is the low level of financial depth (Waldschmidt and Marga 2016). Interest rates are regulated, currently with a minimum deposit interest rate

\footnotetext{
2 The Myanmar Economic Bank (MEB) and the Myanmar Agricultural Development Bank (MADB), established in 1954 and 1953, respectively, and the Myanmar Investment and Commercial Bank (MICB) and Myanmar Foreign Trade Bank (MFTB), both established in 1990 under the first Financial Institutions Law (Chassat and Forster 2016).

3 The Kanbawza Bank, the Ayeyarwady Bank, and the Co-operative Bank. The Kanbawza Bank is by far the biggest (Schellhase and Sun 2017).
} 
requirement of $8 \%$ and a maximum loan interest rate of $13 \%$. The result is that banks focus on fewer and larger customers rather than smaller firms to reduce operational costs (Waldschmidt and Marga 2016). Moreover, loans offered to SMEs do often not differ from regular financial products and therefore do not meet the needs of SMEs in terms of maturity and collateral requirements (Waldschmidt and Marga 2016, p. 77). Accordingly, SMEs have difficulties in obtaining loans from the formal banking system. Many private financial institutions are aware of the growth potential of smaller firms and have started to focus on financial products designed for SMEs. One example is the Small and Medium Industrial Development Bank (SMIDB) which provides subsidized loans to SMEs with at least three years of business experience (SMIDB 2018; Htwe 2017). The subsidized loans come with an interest rate of $8.5 \%$ (Tun 2016; Ko 2018) and the loans have longer maturity periods (3-5 years) compared to regular bank loans (normally only one year), even though the legally imposed one-year cap on maturity has been lifted (Schellhase and Sun 2017). Another initiative came with the introduction of the Microfinance Business Law of 2011, which made microfinance an important source of credit especially to smaller start-ups (Kyaw 2016). These microcredit schemes are explicitly not allowed to require collateral, and annual interest rates are capped at 30\%. However, when it comes to funding for microfinance institutions themselves, regulation requirements are basically the same as for banks. They therefore rely mostly on funds obtained from the MEB and the Myanmar Microfinance Bank. Consequently, smaller microfinance institutions exhibit the same lack of loanable funds access as the traditional banking system (Kyaw 2016).

While the terms of the formal loans are relatively favourable, the application process is complex and demanding. For example, to get a loan from SMIDB the enterprises must first apply at the Central Department of Small and Medium Enterprises Development. Here the application is checked and, if approved, a recommendation is sent to the SMIDB, where the enterprise then officially must apply for the loan (CDEB 2018). Further, the enterprise must be an SME member of the Republic of the Union of Myanmar Federation of Chambers of Commerce and Industry (Aung 2018). ${ }^{4}$ On this background it is no surprise that the application procedure and a generally low level of knowledge about access to finance serve as barriers to loans. In 2014, 41\% of SMEs in Yangon that did not apply for loans stated "that they did not understand or were not familiar with the procedures for bank loans, or bank loan procedures were lengthy and complicated, or both" (Kapteyn and Wah 2016).

\footnotetext{
${ }^{4}$ The required documents for obtaining a SMIDB loan are (1) a loan application form, including a detailed plan for the use of the loan; (2) a copy of National Registration Card and a copy of the household registration of the owner; (3) a copy of the municipal business licence and copies of other relevant ministry licences (if available); (4) the SME membership card; (5) financial statements for the last three years; (6) receipts of revenue tax for the last three years; (7) receipts for the municipal fee or electricity fee for the last month; and (8) various documents concerning the ownership of properties (grant forms 105,106 , and 107, land ownership affidavits, and photos of the building and business).
} 
Banking officials say that "the lack of proper accounts, financial statements and a solid business plan are the main reasons for denying applications" (Aung 2018).

Another constraint is the strict collateral requirements. Banks are in general only allowed to grant fully secured loans with hard collateral, such as land and buildings (Waldschmidt and Marga 2016). While the value of the collateral has to be at least twice the loan size, the requested collateral usually exceeds the loan amount by more than this (Win 2018). Kapteyn and Wah (2016) find the average collateral to be more than five times as valuable as the loans for SMEs in Yangon. The high collateral requirements are difficult to fulfil for many SMEs, and 19\% of the enterprises in Yangon that did not apply for loans between 2012 and 2014 state that the strict collateral requirement was the reason. Banks themselves perceive these requirements as a major constraint, and they report that the approved amount of credit usually depends on the collateral value rather than on the financial needs and the risk profile of the client (Waldschmidt and Marga 2016). Acknowledging this constraint, a credit guarantee insurance (CGI) was introduced in 2014, designed to reimburse lenders to SMEs about $50 \%$ of the loan in the event of default. However, only very few SMEs made use of this scheme as banks have been reluctant to approve CGIbacked loans due to lack of trust in the project's underlying institutional conditions.

\section{Managerial Attributes and Firm Performance}

The strict collateral requirements and complex application procedures in combination with financial illiteracy and the low quality of loan applications accentuate the value of managerial capacity in SMEs when they interact with the formal financial sector. This is a special case of a more general focus on the importance of management practices and managerial capacity for firm performance. The latter is well established for firms of all sizes and from all parts of the World (see, e.g. de Mel et al. 2008; Fafchamps and Woodruff 2017; Bruhn et al. 2018). Building on the ideas in Bloom and Van Reenen (2007), McKenzie and Woodruff (2017) use survey responses about firm owners' and managers' business practices to construct an index of managerial capacity and, using data from seven developing countries, they subsequently show that implementation of new business practices improves firm performance.

Exactly how different management practices influence firm performance is still not fully understood. Bloom et al. (2016) discuss different theories and test a structural model of management practices (management as technology), while McKenzie and Woodruff (2017) take a less structural approach. Specifically, they consider a manager facing a possibly constrained profit maximization problem given as

$$
\begin{aligned}
& \max _{K, L, M} \pi=p f(A, K, L, M)-r K-w L-q M \\
& \text { s.t. } \quad r K+w L+q M \leq \lambda S,
\end{aligned}
$$


where the manager is choosing capital, $K$, labour, $L$, and materials, $M$, to maximize firm profit, $\pi$, with output price, $p$, cost of capital, $r$, cost of labour, $w$, and cost of materials, $q . f(\cdot)$ is the production function with total factor productivity $A$, and the potential credit constraint comes from the restriction that total costs cannot exceed the firm's resources given by a wealth level, $S$, and the tightness of borrowing constraints, reflected in the parameter $\lambda$.

When management is viewed as a technology it is part of the total factor productivity. In this situation better management practices are associated with higher revenue and profits regardless of whether the firm is credit constrained or not. However, better business practices may also affect demand through marketing practices. In the model, this is captured by a higher output price $p$, increasing the revenue and profit in much the same way as changes in the total factor productivity. The manager may also be able to get lower prices on materials or better quality. If so, improved management practices has no direct influence on sales, but they increase profits. Finally, managerial capacity also cover financial planning practices and this may lessen the potential cost constraint by improving access to formal credit. All scenarios give rise to a positive association between managerial capacity and firm performance, conditional on the wealth level, and the empirical analyses in McKenzie and Woodruff (2017) support this association.

While managerial capacity can often be observed through the actual management and business practices or inferred from surveys, this does not necessarily reveal all relevant information about entrepreneurial traits. As shown by Bandiera et al. (2017), although manager traits and management practices are correlated, they are likely to influence aspects of doing business in different ways. For example, both theory and empirical observations on attitudes towards risk indicate that less risk averse individuals have a higher likelihood of becoming entrepreneurs. Empirical studies also find that firms with more risk averse managers have lower profits, on average, than firms with less risk averse managers. In a study of manufacturing enterprises in Ghana, Pattillo and Söderbom (2000) show how firms with more risk averse managers who face high risks have lower profit rate variability and lower average profit rates. In a more recent study of manufacturing SMEs in Vietnam, Sharma and Tarp (2018) find that risk aversion is associated with lower revenue and lower revenue growth. Moreover, in a study of retail shop keepers in Kenya, Kremer et al. (2013) find that loss aversion is associated with lower inventories and profits. The authors conclude that loss aversion may in part explain why some firm managers do not make as high returns investments as expected and, further, that the often found large variations in returns to capital across firms may be due to differences in management capacity. 
In sum, both managerial capacity and attitudes towards risk have been shown to affect firms' sales, profit and investment decisions, and this is to be expected based on a simple model of firm behaviour.

\section{Data}

Our data are from a newly initiated nationally representative survey of micro, small and medium-size enterprises in Myanmar (MEMS). The survey interviewed manufacturing enterprises in the spring and summer of 2017, and it includes both formal and informal enterprises. It is designed to be representative at the state/region level of Myanmar for formal enterprises. While no such claim can be made for the informal firms, their inclusion yields valuable insights. ${ }^{5}$

Following McKenzie and Woodruff (2017), we have constructed a managerial capacity index based on 20 yes/no-questions about business practices related to (1) marketing, (2) stock and buying control, (3) record keeping, and (4) financial planning. The index is computed as the share of these 20 questions for which the manager answers yes. Thus, by construction, the index lies in the interval [0;1], so coefficients can be interpreted as the effect of comparing a manager with no capacity to a manager with excellent capacity. ${ }^{6}$

For attitudes towards risk we rely on self-assessment in the form of questions asking whether the manager is generally a person who tries to avoid taking risks or is fully willing to take risks. The answers are given on an 11-point scale (0-10) where the respondent is instructed that 0 means "unwilling to take risks" and the value 10 means "fully prepared to take risks". The questions were asked first about a general willingness to take risk and subsequently about risk preferences in the contexts of finance- and business-related matters. We add the points for each answer and subsequently re-centre and scale the responses to be in the interval $[-1 ; 1]$ such that negative values are related to risk averse managers, while positive values are associated with risk taking managers. Regression coefficients can be interpreted as comparing an extreme risk averse manager to a risk neutral manager or the risk neutral manager to an extreme risk loving manager. The risk self-assessment has been shown to be predictive of risk taking behaviour in the field in a representative sample (Dohmen et al. 2011) and of experimental risk taking across countries in student samples (Vieider et al. 2015). ${ }^{7}$

Turning to performance variables, we use sales revenues and profits earned over the financial year from 1 April 2016 to 31 March 2017. Both values are selfreported; however, we only include firms for which the operating statements balance. ${ }^{8}$ For investment decisions, we use an indicator taking the value 1 if the firm

\footnotetext{
5 The survey design is described in the Appendix.

6 The individual questions are listed in Table A1 in the Online Appendix.

7 The questions were asked exactly as shown in Dohmen et al. (2011) and Vieider et al. (2015).

8 That is, revenue and all costs (labour, intermediate and indirect) must be positive. Further, gross profits must equal value added less total labour costs and gross profits must be less than the sales revenue.
} 
made investments during the past two years. Analogously, we use an indicator taking the value 1 if the firm made any new or improved existing products or changed specification in the past two years. This is denoted innovation.

Coming last to the measurement of credit demand and constraints, there are three approaches in the literature. One approach is based on firms' perceptions. For example Beck and Demirgüç-Kunt (2006) use a question, which is included in most World Bank "Doing Business" surveys, that ask firms if they perceive themselves as financially constrained and if this is creating an obstacle to their growth.9 This approach is clearly interesting but it is hard to derive a specific policy advise as it is only vaguely linked to the performance of the financial sector. A second approach solves this problem by simply distinguishing between firms that use formal financial services and those that do not (see, e.g. Aterido et al. 2013; Chaudhuri et al. 2018). However, this direct approach may overestimate credit scarcity as some firms do well without formal financial services. This observation led to the third approach, first formulated by Bigsten et al. (2003), in which a distinction is made between firms with and without credit demand. Here, firms can only be credit constrained if they have revealed credit demand.10 Our point of departure is the credit demand approach, but we expand the classification of firms by dividing firms with credit demand into two groups; those that apply for a formal loan, and those that do not apply. The latter group is large in Myanmar and this is important for policy because interventions to address the credit needs for the two groups are very different.

When identifying firms with credit demand we know that firms that applied for a formal loan have credit demand. In addition, firms that did not apply for a loan are classified as having credit demand if the reason for not applying is one of the following: (1) 'the application procedures are too complex', (2) 'the collateral requirements are unattainable', (3) 'the possible loan size and maturity is insufficient', (4) 'interest rates are too high' or (5) 'I did not think it would be approved'. ${ }^{11} \mathrm{We}$ also include firms for which balance sheet information shows positive debt holdings, formal as well as informal ${ }^{12}$ Returning to the firms that applied for credit, we classify them as credit constrained by the formal financial institutions if they applied for and was denied credit regardless of the reason for the rejection. Thus, we keep track of four types of firms: (i) firms with no credit demand, (ii) firms with credit demand that are credit constrained by self-restriction, (iii) firms with credit demand that are credit constrained by the formal banks and (iv) firms with credit demand that are not constrained.

\footnotetext{
9 The MEMS survey also has this question.

10 See Hansen and Rand (2014) for a comparison of the three approaches.

11 Table A2 in the Online Appendix has detailed information about the firms' reasons for not applying, their loan applications (if any) and the banks' reasons for rejections.

12 For firms with incomplete and/or inconsistent balance sheet information, we rely on information about whether firms report having debt larger than current annual revenues.
} 


\section{Methodology}

We estimate the associations between manager characteristics and firm performance using linear models

$$
E\left(y_{i r s}\right)=F\left(\beta_{1} M_{i r s}+\beta_{2} R_{i r s}+\sum_{j=3}^{K} \beta_{j} x_{j i r s}+\alpha_{r}+\delta_{s}\right) \equiv F\left(X_{i r s} \beta\right)
$$

where the outcome variable $y_{i r s}$ is for firm $i$ located in State/Region $r$ and producing goods in sector $s$. In addition to managerial capacity $(M)$ and risk taking behaviour $(R)$ we condition on State/Region fixed effects $\left(\alpha_{r}\right)$ and sector fixed effects $\left(\delta_{s}\right)$. As additional firm level variables $\left(x_{j i r s}\right)$ we include the gender of the manager (female or not), the age of the manager, the age of the firm and the size of the firm (the number of employees). When we use the full sample of firms, we include an indicator for informal firms. The associations with sales and profits are estimated using OLS, while we use probit models for investment and innovation.

We attempt to disentangle the impact of managerial capacity and risk attitudes on formal credit demand and constraints by assuming that debt demand and the decision to apply for a formal loan is taken solely by the firm. Subsequently, if the firm applies for a loan, the decision to grant the loan is made by the financial institution after the loan application has been put forward. As noted above, some firms do not apply even though they have demand. We consider such firms to have credit demand and self-select directly into being credit constrained.

We formulate and estimate the three decisions using two bivariate models with sample selection. For simplicity, we model the probabilities as outcomes of latent firm and bank decisions with normally distributed private information (errors). Letting $d_{i r s}$ denote if firm $i$ in region $r$ and sector $s$ has demand for debt or not and $a_{i r s}$ denote if the firm decides to apply for credit or not, there are three outcomes:

$$
\begin{gathered}
d_{i r s}=0: \quad \mathrm{P}\left(d_{i r s}=0\right)=1-\Phi\left(X_{1 i r s} \beta^{(1)}\right) \\
d_{i r s}=1, a_{i r s}=0: \quad \mathrm{P}\left(d_{i r s}=1, a_{i r s}=0\right)=\Phi\left(X_{1 i r s} \beta^{(1)}\right)-\Phi_{2}\left(X_{1 i r s} \beta^{(1)}, X_{2 i r s} \beta^{(2)}, \rho_{d a}\right) \\
d_{i r s}=1, a_{i r s}=1: \quad \mathrm{P}\left(d_{i r s}=1, a_{i r s}=1\right)=\Phi_{2}\left(X_{1 i r s} \beta^{(1)}, X_{2 i r s} \beta^{(2)}, \rho_{d a}\right)
\end{gathered}
$$

where $\Phi(\cdot)$ and $\Phi_{2}(\cdot)$ are the cumulative distribution functions of standard normal and standard bivariate normal variates, respectively, and $\rho_{d a}$ is the correlation between the errors in the two latent variable regressions. The different indexation of the explanatory variables and regression parameters $\left(X_{1 \text { irs }} \beta^{(1)}, X_{2 \text { irs }} \beta^{(2)}\right)$ indicates that we identify the individual equations by restrictions on the parameters. Equation (2) is the outcome when a firm has no formal credit demand. With no demand it is not meaningful to ask if the firm applies for credit, so the application outcomes do not appear when $d_{i r s}=0$. Equation (3) describes the outcome when a firm has credit demand but does not apply for a formal loan (self-selection into being credit 


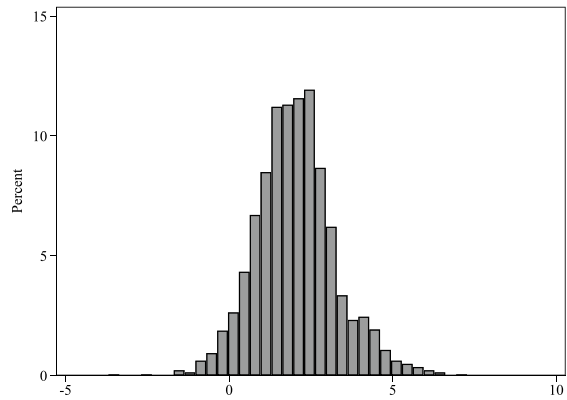

(a) $\ln$ (Sales/employees)

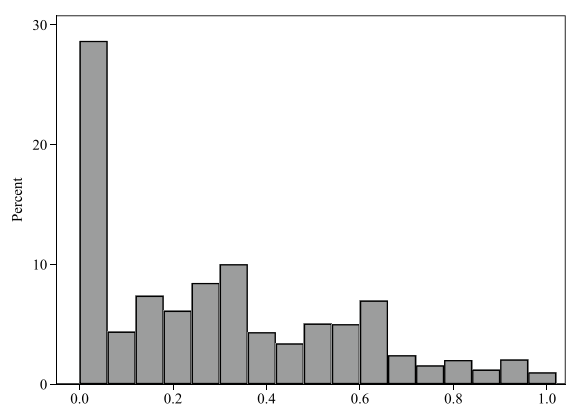

(c) Managerial capacity

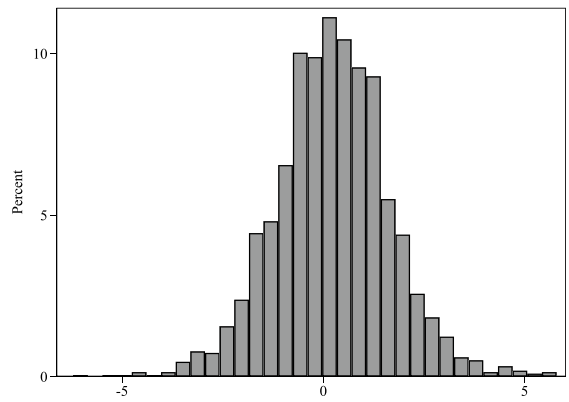

(b) $\ln$ (Profit/employees)

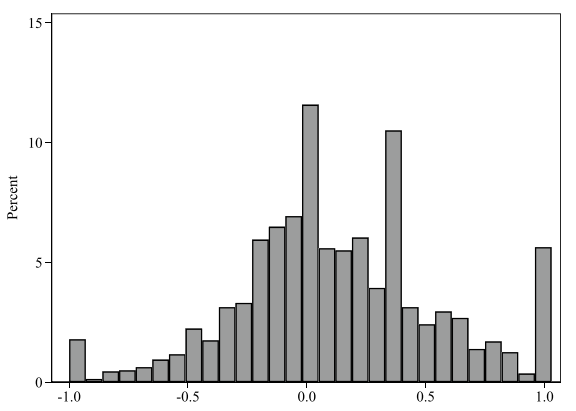

(d) Risk taking

Fig. 1 Distributions of central firm variables. Source Authors' calculations based on MEMS

constrained). Finally, Eq. (4) describes the situation when a firm has credit and applies for a formal loan.

We find that credit demand and the decision to apply for formal credit are conditionally independent $\left[\rho_{d a}=0\right.$, whereby $\left.\Phi_{2}\left(X_{1 i r s} \beta^{(1)}, X_{2 i r s} \beta^{(2)}, \rho_{d a}\right)=\Phi\left(X_{1 i r s} \beta^{(1)}\right) \times \Phi\left(X_{2 i r s} \beta^{(2)}\right)\right]$ and we use this to simplify the modelling of the subsequent decision of the formal bank to grant the loan or not. Specifically, because of the conditional independence, we can again use a bivariate selection model, where we only include firms with credit demand $\left(d_{i r s}=1\right)$ :

$$
a_{i r s}=0 \mid d_{i r s}=1: \quad \mathrm{P}\left(a_{i r s}=0 \mid d_{i r s}=1\right)=1-\frac{\Phi\left(X_{1 i r s} \beta^{(1)}\right) \times \Phi\left(X_{2 i r s} \beta^{(2)}\right)}{\Phi\left(X_{1 i r s} \beta^{(1)}\right)}=1-\Phi\left(X_{2 i r s} \beta^{(2)}\right)
$$




$$
\begin{gathered}
a_{i r s}=1, c_{i r s}=0 \mid d_{i r s}=1: \quad \mathrm{P}\left(a_{i r s}=1, c_{i r s}=0 \mid d_{i r s}=1\right)=\Phi\left(X_{2 i r s} \beta^{(2)}\right)-\Phi_{2}\left(X_{2 i r s} \beta^{(2)}, X_{3 i r s} \beta^{(3)}, \rho_{a c}\right) \\
a_{i r s}=1, c_{i r s}=1 \mid d_{i r s}=1: \quad \mathrm{P}\left(a_{i r s}=1, c_{i r s}=1 \mid d_{i r s}=1\right)=\Phi_{2}\left(X_{2 i r s} \beta^{(2)}, X_{3 i r s} \beta^{(3)}, \rho_{a c}\right) .
\end{gathered}
$$

Here, $c_{i r s}$ shows if the loan application is rejected $\left(c_{i r s}=1\right)$ or not $\left(c_{i r s}=0\right)$. Thus, Eq. (6) is the model for firms that have formal credit, while Eq. (7) describes the credit constrained applicants.

The outcome of the decision made by the formal bank is not represented by the equations above as it is a conditional decision, namely to accept or reject a loan application. Thus, when a formal bank rejects a loan, this is a conditional outcome given by

$$
c_{i r s}=1 \mid\left(a_{i r s}=1, d_{i r s}=1\right): \quad \mathrm{P}\left(c_{i r s}=1 \mid a_{i r s}=1, d_{i r s}=1\right) \quad=\frac{\Phi_{2}\left(X_{2 i r s} \beta^{(2)}, X_{3 i r s} \beta^{(3)}, \rho_{a c}\right)}{\Phi\left(X_{2 i r s} \beta^{(2)}\right)}
$$

We will focus on this outcome when we assess if managerial attributes affect the formal banks' credit allocation.

\section{Results}

\section{Summary Statistics}

Table 1 presents the mean and standard deviation for the variables included in the regressions. ${ }^{13}$ The summary statistics are given for four groups of firms. The first group contains all 2237 firms in our sample. The second group consists of the 1285 firms we categorize as having credit demand (57\% of all firms in the sample). The third group are the firms that self-select into being credit constrained in that they have credit demand, but they do not apply for formal credit. This is a large group of 1091 firms, constituting almost half of all firms and $85 \%$ of the firms with credit demand. The final group is the set of 142 firms that were granted a formal loan. This small group makes up for only $6 \%$ of the full sample, $11 \%$ of the firms with credit demand and $73 \%$ of the firm that applied for a formal loan. Thus, we note that access to formal credit is truly rare for SMEs in Myanmar, and a very large fraction of firms do not approach the banks even though they have demand for credit. ${ }^{14}$

The average sales revenue is 283 million Kyats (about USD 207,546 using the exchange rate for 31 December 2016), while average profits are just below 40 million Kyats (about USD 28,864). Panels (a) and (b) in Fig. 1 presents the distributions

\footnotetext{
13 The standard deviation is only reported for the non-binary variables.

14 Also very few firms rely on informal loans. While $8 \%$ of the firms in the sample have formal debt, only $6 \%$ have informal loans (see Table A3 in the Online Appendix). Furthermore, loans from formal financial institutions are much larger, much cheaper, and have longer maturities than loans obtained informally (see Table A4 in the Online Appendix).
} 
Table 1 Summary statistics

\begin{tabular}{|c|c|c|c|c|}
\hline & All firms & Credit demand & Did not apply & Granted loan \\
\hline Sales (Million Kyat) & $\begin{array}{l}283 \\
(2554)\end{array}$ & $\begin{array}{l}197 \\
(1190)\end{array}$ & $\begin{array}{l}174 \\
(1160)\end{array}$ & $\begin{array}{l}397 \\
(1560)\end{array}$ \\
\hline Profit (Millon Kyat) & $\begin{array}{l}39.4 \\
(326)\end{array}$ & $\begin{array}{l}37.0 \\
(387)\end{array}$ & $\begin{array}{l}34.7 \\
(416)\end{array}$ & $\begin{array}{l}59.3 \\
(195)\end{array}$ \\
\hline Invested & 0.228 & 0.293 & 0.249 & 0.570 \\
\hline Innovated & 0.113 & 0.133 & 0.117 & 0.211 \\
\hline Credit demand & 0.574 & 1.000 & 0.849 & 0.040 \\
\hline Applied for loan & 0.087 & 0.151 & 0.000 & 1.000 \\
\hline Denied loan & 0.023 & 0.040 & 0.000 & 0.000 \\
\hline Managerial capacity & $\begin{array}{l}0.296 \\
(0.267)\end{array}$ & $\begin{array}{l}0.318 \\
(0.265)\end{array}$ & $\begin{array}{l}0.304 \\
(0.259)\end{array}$ & $\begin{array}{l}0.398 \\
(0.293)\end{array}$ \\
\hline Risk taking & $\begin{array}{l}0.126 \\
(0.423)\end{array}$ & $\begin{array}{l}0.173 \\
(0.442)\end{array}$ & $\begin{array}{l}0.161 \\
(0.448)\end{array}$ & $\begin{array}{l}0.228 \\
(0.405)\end{array}$ \\
\hline Female manager & 0.293 & 0.272 & 0.269 & 0.317 \\
\hline Respondent age & $\begin{array}{l}46.8 \\
(12.0)\end{array}$ & $\begin{array}{l}46.5 \\
(11.7)\end{array}$ & $\begin{array}{l}46.1 \\
(11.6)\end{array}$ & $\begin{array}{l}49.4 \\
(12.1)\end{array}$ \\
\hline Firm age & $\begin{array}{l}15.0 \\
(13.2)\end{array}$ & $\begin{array}{l}14.6 \\
(12.8)\end{array}$ & $\begin{array}{l}13.9 \\
(12.6)\end{array}$ & $\begin{array}{l}19.4 \\
(14.2)\end{array}$ \\
\hline Firm size & $\begin{array}{l}12.3 \\
(32.4)\end{array}$ & $\begin{array}{l}10.5 \\
(26.7)\end{array}$ & $\begin{array}{l}9.69 \\
(26.9)\end{array}$ & $\begin{array}{l}15.8 \\
(26.1)\end{array}$ \\
\hline Micro firm (1-4 employed) & 0.511 & 0.513 & 0.549 & 0.275 \\
\hline Micro firm (5-9 employed) & 0.231 & 0.250 & 0.247 & 0.296 \\
\hline Small firm (10-50 employed) & 0.209 & 0.202 & 0.175 & 0.366 \\
\hline Medium firm (50-300 employed) & 0.046 & 0.032 & 0.026 & 0.063 \\
\hline Large firm (300+ employed) & 0.004 & 0.003 & 0.004 & 0.000 \\
\hline Informal firm & 0.142 & 0.156 & 0.177 & 0.042 \\
\hline \multicolumn{5}{|l|}{ MSIC-2 sector } \\
\hline 1063 (Rice mills) & 0.072 & 0.079 & 0.072 & 0.113 \\
\hline 10-12 (Food, beverages, tobacco) & 0.378 & 0.319 & 0.301 & 0.479 \\
\hline 13-15 (Textiles, apparel, leather) & 0.146 & 0.179 & 0.193 & 0.127 \\
\hline 16-18 (Wood, paper, printing) & 0.095 & 0.100 & 0.107 & 0.063 \\
\hline 19-23 (Coke, chemicals, rubber minerals) & 0.089 & 0.086 & 0.092 & 0.042 \\
\hline 24-25 (Metal) & 0.090 & 0.095 & 0.098 & 0.042 \\
\hline 26-30 (Elect. eqpt, machinery, vehicles) & 0.064 & 0.069 & 0.063 & 0.092 \\
\hline 31-33 (Furniture, other. manuf) & 0.065 & 0.073 & 0.073 & 0.042 \\
\hline \multicolumn{5}{|l|}{ State/region } \\
\hline Kachin & 0.047 & 0.074 & 0.081 & 0.014 \\
\hline Kayah & 0.025 & 0.044 & 0.046 & 0.021 \\
\hline Kayin & 0.033 & 0.037 & 0.037 & 0.035 \\
\hline Chin & 0.000 & 0.001 & 0.001 & 0.000 \\
\hline Sagaing & 0.104 & 0.126 & 0.131 & 0.113 \\
\hline Tanintharyi & 0.050 & 0.045 & 0.041 & 0.049 \\
\hline
\end{tabular}


Table 1 (continued)

\begin{tabular}{lllll}
\hline & All firms & Credit demand & Did not apply & Granted loan \\
\hline Bago & 0.077 & 0.041 & 0.037 & 0.077 \\
Magway & 0.076 & 0.066 & 0.060 & 0.099 \\
Mandalay & 0.147 & 0.184 & 0.196 & 0.141 \\
Mon & 0.068 & 0.054 & 0.058 & 0.035 \\
Rakhine & 0.048 & 0.067 & 0.074 & 0.028 \\
Yangon & 0.128 & 0.104 & 0.104 & 0.120 \\
Shan & 0.074 & 0.043 & 0.036 & 0.085 \\
Ayeyarwady & 0.088 & 0.095 & 0.085 & 0.141 \\
Nay Pyi Taw & 0.034 & 0.018 & 0.015 & 0.042 \\
No. of firms & 2237 & 1285 & 1091 & 142 \\
\hline
\end{tabular}

Source Authors' calculations based on MEMS

Chin State hosts less than $0.5 \%$ of the firms. For the continuous variables, the standard deviation is in parenthesis below the mean

of (the log of) sales revenues and profits per employee. The figures illustrate that while there are large dispersions, there are no signs of bunching or extreme outliers in the distributions.

The investment and innovation rates are fairly low as less than $25 \%$ of the firms made investments and $11 \%$ made innovations. Further, as mentioned, $57 \%$ of the firms had credit demand but only $9 \%$ applied for a formal loan in the period and $2 \%$ were denied a loan (almost $25 \%$ of the applicants).

Turning to the managers' attributes, we find that the average managerial capacity is 0.3 (the average manager answers yes to 6 of the 20 questions) with a standard deviation of 0.27 . However, panel (c) in Fig. 1 shows that $25 \%$ of the managers have an index value of 0.05 or 0 . Further, less than $1 \%$ of the managers have a score of 1. The average score is quite a lot lower (about 0.1 point) than the average business practice score across the seven countries in McKenzie and Woodruff (2017), but several of the countries in that study are middle-income countries. The average manager is slightly willing to take risk, while the median manager is very close to risk neutral and panel (d) in Fig. 1 show some bunching at 0 and at the extremes. Even so, we find substantial variation in both indexes. Some $29 \%$ of the managers are female and the average female manager has significantly lower managerial capacity ( 0.025 points), she is more risk averse ( 0.077 points) and she is slightly younger (1.9 years) than her male counterpart. ${ }^{15}$

The average firm has 12 employees; however, the average is heavily influenced by a few very large firms. As seen, half of the firms have 1-4 employees and almost $75 \%$ have less than 10 employees. Based on the summary statistics, firm size appears to have little association with credit demand, whereas there is some connection with formal loan applications and a strong size relation with firms that are granted credit.

15 These statistics are not shown in the table. 
Table 2 Associations of managerial attributes with sales and profits

\begin{tabular}{|c|c|c|c|c|c|c|}
\hline \multirow[t]{2}{*}{ Dependent variable } & \multicolumn{3}{|c|}{$\ln$ (Sales/employees) } & \multicolumn{3}{|c|}{$\ln$ (Profit/employees) } \\
\hline & (1) & (2) & (3) & (4) & (5) & $(6)$ \\
\hline Managerial capacity & $\begin{array}{l}0.344 * * * \\
(0.133)\end{array}$ & & $\begin{array}{l}0.265^{*} \\
(0.138)\end{array}$ & $\begin{array}{l}0.383 * * * \\
(0.145)\end{array}$ & & $\begin{array}{l}0.325 * * \\
(0.154)\end{array}$ \\
\hline Risk taking & & $\begin{array}{l}0.213 * * * \\
(0.077)\end{array}$ & $\begin{array}{l}0.161 * * \\
(0.080)\end{array}$ & & $\begin{array}{l}0.182^{*} \\
(0.093)\end{array}$ & $\begin{array}{l}0.118 \\
(0.099)\end{array}$ \\
\hline Female manager & $\begin{array}{l}-0.104^{*} \\
(0.058)\end{array}$ & $\begin{array}{l}-0.095 \\
(0.058)\end{array}$ & $\begin{array}{l}-0.091 \\
(0.058)\end{array}$ & $\begin{array}{l}-0.093 \\
(0.061)\end{array}$ & $\begin{array}{l}-0.089 \\
(0.060)\end{array}$ & $\begin{array}{l}-0.083 \\
(0.060)\end{array}$ \\
\hline Manager's age & $\begin{array}{l}-0.081 \\
(0.085)\end{array}$ & $\begin{array}{l}-0.078 \\
(0.084)\end{array}$ & $\begin{array}{l}-0.077 \\
(0.085)\end{array}$ & $\begin{array}{l}-0.205^{*} \\
(0.113)\end{array}$ & $\begin{array}{l}-0.203^{*} \\
(0.113)\end{array}$ & $\begin{array}{l}-0.202^{*} \\
(0.113)\end{array}$ \\
\hline Firm size $(\ln )$ & $\begin{array}{l}-0.105^{* *} \\
(0.046)\end{array}$ & $\begin{array}{l}-0.096^{* *} \\
(0.045)\end{array}$ & $\begin{array}{l}-0.111^{* *} \\
(0.046)\end{array}$ & $\begin{array}{l}-0.220 * * * \\
(0.044)\end{array}$ & $\begin{array}{l}-0.207 * * * \\
(0.044)\end{array}$ & $\begin{array}{l}-0.224 * * * \\
(0.044)\end{array}$ \\
\hline Firm age $(\ln )$ & $\begin{array}{l}0.004 \\
(0.033)\end{array}$ & $\begin{array}{l}0.003 \\
(0.032)\end{array}$ & $\begin{array}{l}0.006 \\
(0.032)\end{array}$ & $\begin{array}{l}0.009 \\
(0.037)\end{array}$ & $\begin{array}{l}0.007 \\
(0.037)\end{array}$ & $\begin{array}{l}0.011 \\
(0.037)\end{array}$ \\
\hline Informal firm & $\begin{array}{l}-0.396 * * * \\
(0.085)\end{array}$ & $\begin{array}{l}-0.419 * * * \\
(0.087)\end{array}$ & $\begin{array}{l}-0.400 * * * \\
(0.085)\end{array}$ & $\begin{array}{l}-0.281 \text { *** } \\
(0.096)\end{array}$ & $\begin{array}{l}-0.306^{* * * *} \\
(0.096)\end{array}$ & $\begin{array}{l}-0.284 * * * \\
(0.097)\end{array}$ \\
\hline$R^{2}$ & 0.504 & 0.504 & 0.506 & 0.379 & 0.378 & 0.380 \\
\hline Observations & 2237 & 2237 & 2237 & 2237 & 2237 & 2237 \\
\hline
\end{tabular}

Source Authors' calculations based on MEMS

All regressions include sector fixed effects and Region/State fixed effects. The profit regressions also include an indicator variable taking the value 1 when profits are negative. Township $\times$ sector clustered standard errors are in parentheses

**** $p<0.01, * * p<0.05, * p<0.1$

The small and medium-size firms make up for $2 / 3$ of the firms with formal credit, while they are less than $1 / 4$ of the firms with credit demand.

In the sector classification, we use the Myanmar Standard Industrial Classification (MSIC) codes, which we group into eight aggregate sectors as seen in Table 1. Rice mills comprise $28 \%$ of the manufacturing sector in Myanmar, so they are placed in their own group. The food, beverages and tobacco sector (excluding rice mills) is by far the largest with almost $40 \%$ of the firms. The second largest sector is textiles, apparel and leather, but this sector is with $15 \%$ of the firms less than half the size of the food and tobacco group.

The lower part of Table 1 gives the regional distribution of the firms. Most are located in the manufacturing centres, Mandalay and Yangon, and in Sagaing. These regions are part of the central area of Myanmar, surrounded by mountains in the north west, and east, and by sea in the west and south. Yangon, Mandalay, and Nay Pyi Taw are both the largest cities and the political centres, with Nay Pyi Taw being the capital, Yangon the former capital until 2005, and Mandalay the last capital before British colonization. Less than $0.5 \%$ of the firms are located in Chin State, 
Table 3 Associations of managerial attributes with investment and innovation

\begin{tabular}{|c|c|c|c|c|c|c|}
\hline \multirow[t]{2}{*}{ Dependent variable } & \multicolumn{3}{|l|}{ Invested } & \multicolumn{3}{|l|}{ Innovated } \\
\hline & (1) & (2) & (3) & (4) & $(5)$ & (6) \\
\hline Managerial capacity & $\begin{array}{l}0.186 * * * \\
(0.048)\end{array}$ & & $\begin{array}{l}0.168 * * * \\
(0.055)\end{array}$ & $\begin{array}{l}0.210^{* * *} \\
(0.026)\end{array}$ & & $\begin{array}{l}0.192 * * * \\
(0.027)\end{array}$ \\
\hline Risk taking & & $\begin{array}{l}0.072 * * \\
(0.031)\end{array}$ & $\begin{array}{l}0.039 \\
(0.034)\end{array}$ & & $\begin{array}{l}0.078^{* * *} \\
(0.020)\end{array}$ & $\begin{array}{l}0.036^{*} \\
(0.019)\end{array}$ \\
\hline Female manager & $\begin{array}{l}-0.024 \\
(0.020)\end{array}$ & $\begin{array}{l}-0.025 \\
(0.022)\end{array}$ & $\begin{array}{l}-0.021 \\
(0.021)\end{array}$ & $\begin{array}{l}-0.029 * \\
(0.017)\end{array}$ & $\begin{array}{l}-0.033^{* *} \\
(0.017)\end{array}$ & $\begin{array}{l}-0.026 \\
(0.017)\end{array}$ \\
\hline Manager's age & $\begin{array}{l}-0.050 \\
(0.037)\end{array}$ & $\begin{array}{l}-0.051 \\
(0.038)\end{array}$ & $\begin{array}{l}-0.050 \\
(0.037)\end{array}$ & $\begin{array}{l}-0.024 \\
(0.025)\end{array}$ & $\begin{array}{l}-0.025 \\
(0.026)\end{array}$ & $\begin{array}{l}-0.024 \\
(0.025)\end{array}$ \\
\hline Firm size (ln) & $\begin{array}{l}0.058 * * * \\
(0.012)\end{array}$ & $\begin{array}{l}0.066^{* * *} \\
(0.011)\end{array}$ & $\begin{array}{l}0.056^{* * *} \\
(0.011)\end{array}$ & $\begin{array}{l}0.016 * * \\
(0.007)\end{array}$ & $\begin{array}{l}0.027 * * * \\
(0.007)\end{array}$ & $\begin{array}{l}0.015 * * \\
(0.007)\end{array}$ \\
\hline Firm age $(\ln )$ & $\begin{array}{l}-0.008 \\
(0.011)\end{array}$ & $\begin{array}{l}-0.010 \\
(0.011)\end{array}$ & $\begin{array}{l}-0.008 \\
(0.011)\end{array}$ & $\begin{array}{l}0.008 \\
(0.007)\end{array}$ & $\begin{array}{l}0.006 \\
(0.007)\end{array}$ & $\begin{array}{l}0.009 \\
(0.007)\end{array}$ \\
\hline Informal firm & $\begin{array}{l}-0.009 \\
(0.034)\end{array}$ & $\begin{array}{l}-0.022 \\
(0.034)\end{array}$ & $\begin{array}{l}-0.010 \\
(0.034)\end{array}$ & $\begin{array}{l}0.011 \\
(0.023)\end{array}$ & $\begin{array}{l}-0.006 \\
(0.024)\end{array}$ & $\begin{array}{l}0.010 \\
(0.023)\end{array}$ \\
\hline Pseudo $R^{2}$ & 0.108 & 0.100 & 0.109 & 0.172 & 0.139 & 0.175 \\
\hline Observations & 2236 & 2236 & 2236 & 2236 & 2236 & 2236 \\
\hline
\end{tabular}

Source Authors' calculations based on MEMS

The table reports average marginal effects. All regressions include sector fixed effects and Region/State fixed effects. The single firm in Chin state is omitted because the Region/State fixed effect predicts the outcome perfectly. Township $\times$ sector clustered standard errors are in parentheses

$* * * p<0.01, * * p<0.05, * p<0.1$

so in some regressions these firms are omitted as the state fixed effect completely determines the outcome.

The changes in the summary statistics when moving from left to right in Table 1 are telling, though not surprising. Firms with credit demand have lower sales, in part because they are smaller, though not significantly lower profits than firms without demand. More of the firms have invested and innovated and the managers are significantly more capable and more willing to take risk. Moving further to the group of firms that do not apply for formal credit even though they have a need for credit, there is yet a drop in both sales, profits and firm size. In this group, managerial capacity is on par with the overall average and we find the same level of dispersion. Further, the propensity to invest and innovate and the willingness to take risk are still above the overall average. Finally, the small group of firms with formal credit have above average attributes in all respects. On average, they have much higher sales, profits and they are larger. More than half of the firms have invested and onein-five have innovated. These shares are about twice the size of the overall ratios. 
Table 4 Estimated average changes in the probability of (A) having credit demand, (B) applying for formal credit, conditional on credit demand, and (C) applying for credit

\begin{tabular}{|c|c|c|c|c|c|c|}
\hline & \multicolumn{3}{|c|}{ Formal firms } & \multicolumn{3}{|l|}{ All firms } \\
\hline & (1) & (2) & (3) & (4) & (5) & $(6)$ \\
\hline \multicolumn{7}{|c|}{ A: Probability of credit demand } \\
\hline Managerial capacity & $\begin{array}{l}0.136 * * * \\
(0.047)\end{array}$ & & $\begin{array}{l}0.097 * * \\
(0.045)\end{array}$ & $\begin{array}{l}0.127 * * * \\
(0.048)\end{array}$ & & $\begin{array}{l}0.087^{*} \\
(0.045)\end{array}$ \\
\hline Risk taking & & $\begin{array}{l}0.099 * * * \\
(0.030)\end{array}$ & $\begin{array}{l}0.078^{* * *} \\
(0.030)\end{array}$ & & $\begin{array}{l}0.095^{* * *} \\
(0.029)\end{array}$ & $\begin{array}{l}0.077 \text { *** } \\
(0.027)\end{array}$ \\
\hline Female manager & $\begin{array}{l}-0.041^{*} \\
(0.023)\end{array}$ & $\begin{array}{l}-0.036 \\
(0.023)\end{array}$ & $\begin{array}{l}-0.034 \\
(0.024)\end{array}$ & $\begin{array}{l}-0.051^{* *} \\
(0.023)\end{array}$ & $\begin{array}{l}-0.046^{* *} \\
(0.023)\end{array}$ & $\begin{array}{l}-0.045^{*} \\
(0.023)\end{array}$ \\
\hline Manager's age & $\begin{array}{l}-0.047 \\
(0.046)\end{array}$ & $\begin{array}{l}-0.046 \\
(0.047)\end{array}$ & $\begin{array}{l}-0.045 \\
(0.047)\end{array}$ & $\begin{array}{l}-0.040 \\
(0.041)\end{array}$ & $\begin{array}{l}-0.038 \\
(0.042)\end{array}$ & $\begin{array}{l}-0.038 \\
(0.041)\end{array}$ \\
\hline Firm size (ln) & $\begin{array}{l}-0.023^{*} \\
(0.013)\end{array}$ & $\begin{array}{l}-0.019 \\
(0.013)\end{array}$ & $\begin{array}{l}-0.025^{* *} \\
(0.013)\end{array}$ & $\begin{array}{l}-0.018 \\
(0.013)\end{array}$ & $\begin{array}{l}-0.016 \\
(0.012)\end{array}$ & $\begin{array}{l}-0.021 \\
(0.013)\end{array}$ \\
\hline Firm age $(\ln )$ & $\begin{array}{l}-0.006 \\
(0.013)\end{array}$ & $\begin{array}{l}-0.006 \\
(0.013)\end{array}$ & $\begin{array}{l}-0.005 \\
(0.013)\end{array}$ & $\begin{array}{l}0.003 \\
(0.012)\end{array}$ & $\begin{array}{l}0.003 \\
(0.012)\end{array}$ & $\begin{array}{l}0.004 \\
(0.012)\end{array}$ \\
\hline Informal firm & & & & $\begin{array}{l}0.019 \\
(0.030)\end{array}$ & $\begin{array}{l}0.011 \\
(0.030)\end{array}$ & $\begin{array}{l}0.017 \\
(0.030)\end{array}$ \\
\hline \multicolumn{7}{|c|}{ B: Probability of applying for formal credit, conditional on credit demand } \\
\hline Managerial capacity & $\begin{array}{l}0.125 * * * \\
(0.045)\end{array}$ & & $\begin{array}{l}0.115^{* *} \\
(0.048)\end{array}$ & $\begin{array}{l}0.110^{* * * *} \\
(0.040)\end{array}$ & & $\begin{array}{l}0.098^{* *} \\
(0.043)\end{array}$ \\
\hline Risk taking & & $\begin{array}{l}0.044 \\
(0.032)\end{array}$ & $\begin{array}{l}0.021 \\
(0.034)\end{array}$ & & $\begin{array}{l}0.043 \\
(0.028)\end{array}$ & $\begin{array}{l}0.024 \\
(0.030)\end{array}$ \\
\hline Female manager & $\begin{array}{l}0.031 \\
(0.031)\end{array}$ & $\begin{array}{l}0.030 \\
(0.031)\end{array}$ & $\begin{array}{l}0.032 \\
(0.031)\end{array}$ & $\begin{array}{l}0.027 \\
(0.026)\end{array}$ & $\begin{array}{l}0.027 \\
(0.027)\end{array}$ & $\begin{array}{l}0.028 \\
(0.027)\end{array}$ \\
\hline Manager's age & $\begin{array}{l}0.056 \\
(0.042)\end{array}$ & $\begin{array}{l}0.050 \\
(0.043)\end{array}$ & $\begin{array}{l}0.054 \\
(0.042)\end{array}$ & $\begin{array}{l}0.059 \\
(0.040)\end{array}$ & $\begin{array}{l}0.053 \\
(0.041)\end{array}$ & $\begin{array}{l}0.058 \\
(0.040)\end{array}$ \\
\hline Firm size $(\ln )$ & $\begin{array}{l}0.054 * * * \\
(0.013)\end{array}$ & $\begin{array}{l}0.062 * * * \\
(0.013)\end{array}$ & $\begin{array}{l}0.053^{* * *} \\
(0.013)\end{array}$ & $\begin{array}{l}0.049^{* * * *} \\
(0.012)\end{array}$ & $\begin{array}{l}0.055^{* * *} \\
(0.012)\end{array}$ & $\begin{array}{l}0.047^{* * *} \\
(0.012)\end{array}$ \\
\hline Firm age $(\ln )$ & $\begin{array}{l}0.042 * * * \\
(0.013)\end{array}$ & $\begin{array}{l}0.041 * * * \\
(0.014)\end{array}$ & $\begin{array}{l}0.042 * * * \\
(0.013)\end{array}$ & $\begin{array}{l}0.036 \text { *** } \\
(0.012)\end{array}$ & $\begin{array}{l}0.035^{* * *} \\
(0.013)\end{array}$ & $\begin{array}{l}0.037 * * * \\
(0.012)\end{array}$ \\
\hline Informal firm & & & & $\begin{array}{l}-0.120^{* *} \\
(0.048)\end{array}$ & $\begin{array}{l}-0.131^{* * *} \\
(0.048)\end{array}$ & $\begin{array}{l}-0.121^{* *} \\
(0.048)\end{array}$ \\
\hline \multicolumn{7}{|c|}{ C: Probability of credit demand and applying for formal credit } \\
\hline Managerial capacity & $\begin{array}{l}0.092 * * * \\
(0.025)\end{array}$ & & $\begin{array}{l}0.079 * * * \\
(0.027)\end{array}$ & $\begin{array}{l}0.080^{* * * *} \\
(0.022)\end{array}$ & & $\begin{array}{l}0.067 * * * \\
(0.024)\end{array}$ \\
\hline Risk taking & & $\begin{array}{l}0.043 * * * \\
(0.016)\end{array}$ & $\begin{array}{l}0.026 \\
(0.017)\end{array}$ & & $\begin{array}{l}0.040^{* * *} \\
(0.015)\end{array}$ & $\begin{array}{l}0.026^{*} \\
(0.015)\end{array}$ \\
\hline Female manager & $\begin{array}{l}0.008 \\
(0.016)\end{array}$ & $\begin{array}{l}0.008 \\
(0.017)\end{array}$ & $\begin{array}{l}0.010 \\
(0.017)\end{array}$ & $\begin{array}{l}0.005 \\
(0.014)\end{array}$ & $\begin{array}{l}0.006 \\
(0.015)\end{array}$ & $\begin{array}{l}0.007 \\
(0.015)\end{array}$ \\
\hline Manager's age & $\begin{array}{l}0.020 \\
(0.022)\end{array}$ & $\begin{array}{l}0.017 \\
(0.023)\end{array}$ & $\begin{array}{l}0.020 \\
(0.023)\end{array}$ & $\begin{array}{l}0.024 \\
(0.022)\end{array}$ & $\begin{array}{l}0.021 \\
(0.023)\end{array}$ & $\begin{array}{l}0.024 \\
(0.023)\end{array}$ \\
\hline
\end{tabular}


Table 4 (continued)

\begin{tabular}{|c|c|c|c|c|c|c|}
\hline & \multicolumn{3}{|c|}{ Formal firms } & \multicolumn{3}{|l|}{ All firms } \\
\hline & (1) & (2) & (3) & (4) & (5) & (6) \\
\hline \multirow[t]{2}{*}{ Firm size (ln) } & $0.024 * * *$ & $0.028 * * *$ & $0.023 * * *$ & $0.022 * * *$ & $0.026^{* * * *}$ & $0.021 * * *$ \\
\hline & $(0.008)$ & $(0.007)$ & $(0.008)$ & $(0.007)$ & $(0.007)$ & $(0.007)$ \\
\hline \multirow[t]{2}{*}{ Firm age (ln) } & $0.021 * * *$ & $0.020 * *$ & $0.021 * * *$ & $0.020^{* * *} *$ & $0.019 * *$ & $0.020 * * *$ \\
\hline & $(0.008)$ & $(0.008)$ & $(0.008)$ & $(0.007)$ & $(0.008)$ & $(0.008)$ \\
\hline \multirow[t]{2}{*}{ Informal firm } & & & & $-0.060 * *$ & $-0.066^{* *}$ & $-0.061^{* *}$ \\
\hline & & & & $(0.026)$ & $(0.026)$ & $(0.026)$ \\
\hline Test of independence & 0.818 & 0.986 & 0.858 & 0.975 & 0.804 & 0.960 \\
\hline Observations & 1920 & 1920 & 1920 & 2237 & 2237 & 2237 \\
\hline
\end{tabular}

Source Authors' calculations based on MEMS

All regressions include sector fixed effects and Region/State fixed effects. The estimated probabilities are based on the regressions given in Table A5 in the Online Appendix. Township $\times$ sector clustered standard errors are in parentheses

$* * * p<0.01, * * p<0.05, * p<0.1$

\section{Firm Performance}

Table 2 reports regression results for sales and profits. For both variables we scale by the number of employees and take the logarithm. ${ }^{16}$ As such, the results can be interpreted as associations with labour productivity instead of sales and profits. Column (1) shows a strong positive and statistically significant link between larger sales (or labour productivity) and managerial capacity. A one-quarter increase in managerial capacity (i.e. about one standard deviation) is associated with an increase in sales per employee of $13 \%$. The order of magnitude is similar for profits, as seen from column (4) in the table. Willingness to take risk is also positively associated with sales as seen from column (2). Here, we find that an increase of one-half score (just above one standard deviation), is associated with an increase in sales of $11 \%$. The association with profits is more uncertain and smaller in magnitude. When both attributes are included in columns (3) and (6) the individual associations with sales and profits decrease and they become less precisely determined ${ }^{17}$ However, the association with managerial capacity is marginally significant for both sales and profits. In that sense our results are reasonably well in line with the findings in McKenzie and Woodruff (2017).

Table 3 reports the results for investment and innovation in the form of estimated average marginal effects based on probit regressions. Managerial capacity appears strongly associated with both the decision to invest and to innovate, as seen from columns (1) and (4), and the associations are not strongly affected by inclusion

\footnotetext{
${ }^{16}$ For 52 firms that had negative profits, we have recorded log-profits of 0 and include a dummy for these firms.

17 The correlation between the two attributes is 0.4 .
} 
of the willingness to take risk as seen from columns (3) and (6) in the table. An increase in managerial capacity of one-quarter is associated with an increase in the probability of investing just above 4 percentage points. Given the low frequency of investing firms, this is substantial (a 17\% increase at the mean). The association with risk taking behaviour is weaker. Here we find that a 0.5 point increase in the risk score is associated with an increase in the probability of investing of 3.6 percentage point. However, the association drops to half the size when managerial capacity is also included, and it is no longer statistically significant. The picture is very similar for innovation, albeit the effect of higher managerial capacity is larger, about a 5 percentage point increase in the probability of innovating associated with a 0.25 point increase in managerial capacity, which is a relative change of about $50 \%$ when evaluated at the mean.

Overall, our regressions lend support to results from other countries showing that managerial capacity and personality traits are positively associated with firm performance and investment decisions. Based on this confirmation we turn to the associations with credit demand and constraints.

\section{Credit demand and constraints}

In the analysis of firm performance we included all firms in all regressions regardless of their formal status. We took account of differences between formal and informal firms by including an indicator for the latter group. As noted above, informal firms have much lower revenues and profits per worker on average, but we find no differences in investment and innovation probabilities. However, the distinction between formal and informal enterprises may be more important when looking at formal credit demand and access. Informal firms are not eligible for formal loans in the company name, but they may obtain formal financing based on personal wealth records or through microcredit, which does not require collateral. Consequently, we report the results for credit demand and access for the formal firms and subsequently for all firms in the tables below. When the informal firms are included we also include the indicator variable for these firms in the regressions.

We present the credit results by reporting the estimated average marginal effects of changes in the variables of interest on the probabilities of the different events given in Eqs. (2)-(8). The marginal effects on the probability of a credit demand and the probability of the firm applying for a formal loan are given in Table 4 . The estimated log-odds ratios for the regression models are given in Table A5 in the Online Appendix.

We do not have experimental variation to identify the two decisions, so we must resort to (economic) reasoning. We argue that managers who answer 'no' to a question of whether 'shortage of capital is the main obstacle to growth' should have a lower probability of demanding credit compared to firms with managers who answer yes to the question. At the same time, conditional on the credit demand and the manager's attributes, the manager's perception of obstacles should not influence if the manager applies for a formal loan or not. Clearly, it could be reasoned that a 
Table 5 Estimated average changes in the probability of (A) applying for credit, (B) being rejected, conditional on applying, and (C) getting credit

\begin{tabular}{|c|c|c|c|c|c|c|}
\hline & \multicolumn{3}{|c|}{ Formal firms } & \multicolumn{3}{|l|}{ All firms } \\
\hline & $(1)$ & $(2)$ & (3) & (4) & $(5)$ & $(6)$ \\
\hline \multicolumn{7}{|c|}{ A: Probability of applying for credit (conditional on demand) } \\
\hline Managerial capacity & $\begin{array}{l}0.111^{* * * *} \\
(0.042)\end{array}$ & & $\begin{array}{l}0.101^{* *} \\
(0.045)\end{array}$ & $\begin{array}{l}0.098 \text { *** } \\
(0.038)\end{array}$ & & $\begin{array}{l}0.087^{* *} \\
(0.040)\end{array}$ \\
\hline Risk taking & & $\begin{array}{l}0.040 \\
(0.030)\end{array}$ & $\begin{array}{l}0.020 \\
(0.031)\end{array}$ & & $\begin{array}{l}0.039 \\
(0.026)\end{array}$ & $\begin{array}{l}0.023 \\
(0.027)\end{array}$ \\
\hline Female manager & $\begin{array}{l}0.018 \\
(0.049)\end{array}$ & $\begin{array}{l}0.017 \\
(0.047)\end{array}$ & $\begin{array}{l}0.020 \\
(0.047)\end{array}$ & $\begin{array}{l}0.021 \\
(0.036)\end{array}$ & $\begin{array}{l}0.020 \\
(0.038)\end{array}$ & $\begin{array}{l}0.023 \\
(0.035)\end{array}$ \\
\hline Firm size (ln) & $\begin{array}{l}0.051^{* * * *} \\
(0.013)\end{array}$ & $\begin{array}{l}0.058^{* * * *} \\
(0.013)\end{array}$ & $\begin{array}{l}0.050 * * * \\
(0.013)\end{array}$ & $\begin{array}{l}0.044 * * * \\
(0.011)\end{array}$ & $\begin{array}{l}0.050^{* * *} \\
(0.011)\end{array}$ & $\begin{array}{l}0.043 * * * \\
(0.011)\end{array}$ \\
\hline Firm age $(\ln )$ & $\begin{array}{l}0.044 * * * \\
(0.013)\end{array}$ & $\begin{array}{l}0.042 * * * \\
(0.013)\end{array}$ & $\begin{array}{l}0.044 * * * \\
(0.013)\end{array}$ & $\begin{array}{l}0.038 * * * \\
(0.011)\end{array}$ & $\begin{array}{l}0.037 * * * \\
(0.012)\end{array}$ & $\begin{array}{l}0.038 * * * \\
(0.011)\end{array}$ \\
\hline Informal firm & & & & $\begin{array}{l}-0.108^{* *} \\
(0.044)\end{array}$ & $\begin{array}{l}-0.117^{* * * *} \\
(0.044)\end{array}$ & $\begin{array}{l}-0.109^{* *} \\
(0.045)\end{array}$ \\
\hline \multicolumn{7}{|c|}{ B: Probability of being rejected, conditional on applying } \\
\hline Managerial capacity & $\begin{array}{l}0.034 \\
(0.131)\end{array}$ & & $\begin{array}{l}0.020 \\
(0.127)\end{array}$ & $\begin{array}{l}0.025 \\
(0.120)\end{array}$ & & $\begin{array}{l}0.017 \\
(0.118)\end{array}$ \\
\hline Risk taking & & $\begin{array}{l}0.030 \\
(0.083)\end{array}$ & $\begin{array}{l}0.028 \\
(0.079)\end{array}$ & & $\begin{array}{l}0.017 \\
(0.076)\end{array}$ & $\begin{array}{l}0.015 \\
(0.073)\end{array}$ \\
\hline Female manager & $\begin{array}{l}0.015 \\
(0.019)\end{array}$ & $\begin{array}{l}0.015 \\
(0.021)\end{array}$ & $\begin{array}{l}0.016 \\
(0.020)\end{array}$ & $\begin{array}{l}0.008 \\
(0.036)\end{array}$ & $\begin{array}{l}0.010 \\
(0.028)\end{array}$ & $\begin{array}{l}0.006 \\
(0.038)\end{array}$ \\
\hline Firm size $(\ln )$ & $\begin{array}{l}-0.008 \\
(0.041)\end{array}$ & $\begin{array}{l}-0.007 \\
(0.038)\end{array}$ & $\begin{array}{l}-0.010 \\
(0.042)\end{array}$ & $\begin{array}{l}-0.016 \\
(0.036)\end{array}$ & $\begin{array}{l}-0.014 \\
(0.035)\end{array}$ & $\begin{array}{l}-0.017 \\
(0.037)\end{array}$ \\
\hline Firm age (ln) & $\begin{array}{l}-0.068^{*} \\
(0.039)\end{array}$ & $\begin{array}{l}-0.067 * \\
(0.037)\end{array}$ & $\begin{array}{l}-0.066^{*} \\
(0.038)\end{array}$ & $\begin{array}{l}-0.064^{*} \\
(0.035)\end{array}$ & $\begin{array}{l}-0.064 * \\
(0.035)\end{array}$ & $\begin{array}{l}-0.062 * \\
(0.035)\end{array}$ \\
\hline Informal firm & & & & $\begin{array}{l}-0.152 \\
(0.166)\end{array}$ & $\begin{array}{l}-0.154 \\
(0.171)\end{array}$ & $\begin{array}{l}-0.159 \\
(0.164)\end{array}$ \\
\hline \multicolumn{7}{|c|}{ C: Probability of getting credit (conditional on demand) } \\
\hline Managerial capacity & $\begin{array}{l}0.074 * * \\
(0.035)\end{array}$ & & $\begin{array}{l}0.070^{*} \\
(0.037)\end{array}$ & $\begin{array}{l}0.067 * * \\
(0.032)\end{array}$ & & $\begin{array}{l}0.060^{*} \\
(0.034)\end{array}$ \\
\hline Risk taking & & $\begin{array}{l}0.023 \\
(0.024)\end{array}$ & $\begin{array}{l}0.009 \\
(0.025)\end{array}$ & & $\begin{array}{l}0.026 \\
(0.021)\end{array}$ & $\begin{array}{l}0.014 \\
(0.022)\end{array}$ \\
\hline Female manager & $\begin{array}{l}0.010 \\
(0.034)\end{array}$ & $\begin{array}{l}0.010 \\
(0.032)\end{array}$ & $\begin{array}{l}0.012 \\
(0.034)\end{array}$ & $\begin{array}{l}0.014 \\
(0.030)\end{array}$ & $\begin{array}{l}0.013 \\
(0.030)\end{array}$ & $\begin{array}{l}0.016 \\
(0.029)\end{array}$ \\
\hline Firm size (ln) & $\begin{array}{l}0.038^{* * * *} \\
(0.010)\end{array}$ & $\begin{array}{l}0.043^{* * *} \\
(0.010)\end{array}$ & $\begin{array}{l}0.038^{* * *} \\
(0.010)\end{array}$ & $\begin{array}{l}0.035^{* * *} \\
(0.009)\end{array}$ & $\begin{array}{l}0.038 * * * \\
(0.009)\end{array}$ & $\begin{array}{l}0.034 * * * \\
(0.009)\end{array}$ \\
\hline Firm age (ln) & $\begin{array}{l}0.043 * * * \\
(0.013)\end{array}$ & $\begin{array}{l}0.042 * * * \\
(0.013)\end{array}$ & $\begin{array}{l}0.043 * * * \\
(0.013)\end{array}$ & $\begin{array}{l}0.037 * * * \\
(0.011)\end{array}$ & $\begin{array}{l}0.037 * * * \\
(0.011)\end{array}$ & $\begin{array}{l}0.037 * * * \\
(0.011)\end{array}$ \\
\hline Informal firm & & & & $\begin{array}{l}-0.054 \\
(0.041)\end{array}$ & $\begin{array}{l}-0.061 \\
(0.041)\end{array}$ & $\begin{array}{l}-0.054 \\
(0.041)\end{array}$ \\
\hline Test of independence & 0.665 & 0.609 & 0.687 & 0.866 & 0.810 & 0.887 \\
\hline
\end{tabular}


Table 5 (continued)

Formal firms All firms

(1)

Observations
(2)

1085
(4)

1085

All firms

Source Authors' calculations based on MEMS

All regressions include sector fixed effects and Region/State fixed effects. The equation for rejections has only 3 sector fixed effects, corresponding to the firms' MSIC-1 codes. The estimated probabilities are based on the regressions given in Table A6 in the Online Appendix. Township $\times$ sector clustered standard errors are in parentheses

$* * * p<0.01, * * p<0.05, * p<0.1$

manager who perceives shortage of capital as being a major obstacle has a higher likelihood of applying for a loan. Yet, we argue that conditionally on credit demand the decision to apply for a loan depends on the capacity of the manager, not on the credit obstacle perception as such. Hence, we include an indicator taking the value 1 if the manager does not perceive shortage of capital to be the main obstacle to growth in the equation estimating demand for credit, while we exclude the indicator from the application equation. This exclusion restriction (formally) identifies the two equations independently of the functional form assumption.

Table 4 shows results for sets of six regressions. Columns (1)-(3) are for the sample of registered firms, while columns (4)-(6) are for the full sample, including the informal firms. Panel A presents the results for credit demand. The estimated partial effects of managerial capacity and risk behaviour are unaffected of the inclusion, or not, of the informal firms. For the other regressors, some of the small changes turns marginally significant parameter estimates insignificant (firm size), and vice versa (female manager). In both samples, higher managerial capacity is clearly associated with a higher probability of credit demand. An increase of 0.25 points in the capacity shows up as an expected 2.5 percentage point increase in demand. An increase in the risk taking score of 0.5 comes with an expected increase of 4-5 percentage points in the probability of debt demand. Thus, relative to firm performance and investment behaviour, risk appears to have a larger influence on credit demand in comparison with managerial capacity.

Panel B reports the partial changes in the probability that a firm actually applies for a formal loan, conditional on having credit demand. By showing the parameters of the conditional distribution we illustrate the difference in the influence of managerial capacity and risk taking. Conditional on credit demand, risk taking managers are no more likely to apply for formal credit than managers who avoid taking risk. In contrast, the conditional probability of applying is strongly associated with managerial capacity. The order of magnitude is similar to the association with credit demand. Hence, more capable managers are less likely to hold back from applying when they need credit. Panel B also shows how larger and older firms are more likely to apply for formal credit, even if the probability of credit demand may be slightly lower for larger firms compared to smaller ones. 
The combined outcomes of the partial effects are given in Panel $\mathrm{C}$ in which we report the associations with the overall probability of applying for a formal loan. The signs and relative orders of magnitude should correspond reasonably well with the summary statistics. As seen the model predicts that larger and older firms are more frequent applicants, informal firms are less frequent, and firms with more capable and more risk taking managers are also more frequent applicants. This corresponds well with the summary statistics.

The next to last row in Table 4 has $p$ values of tests for independence of the two error terms (i.e. $\rho_{d a}=0$ ). As seen, it is highly likely that they actually are independent and, as noted above, we utilize this result by imposing independence in the next set of regressions describing the application for, and rejection of, formal credit.

Table 5 shows the average marginal changes in the probabilities of applying for credit (Panel A), being rejected given the application (Panel B), and finally of getting formal credit (Panel C). The coefficients in Panel A corresponds to the estimates in Panel B of Table 4 with small differences caused by imposing independence of the credit demand and because we have omitted the manager's age as regressor. We have also reduced the number of sector fixed effects in the equation for rejections from 8 to 3 sectors. The exclusions were necessary to achieve convergence of the estimation procedure. The difficulties arise because of the very few firms that actually applied for credit.

Panel B shows estimates of the influence of managerial capacity and risk taking behaviour on the formal bank's decision to grant credit. As seen, we find than nothing but firm age has a reasonably systematic association with the decision. And even this association is uncertain being only marginally significant at the $10 \%$ level. Thus, conditional on the production sectors and location fixed effects we find no systematic variation in rejecting versus granting credit. This may of course be due to the low power we have in the regression as only 194 firms applied for formal credit (and of these 52 firms did not get credit).

Panel $\mathrm{C}$ shows the association between firm attributes and the probability of having formal credit, conditional on having credit demand. Despite the insignificant influence of managerial capacity on the formal banks' decisions, there is an association through high capacity managers' higher probability of applying for credit. The same effect ensures that larger and older firms are more likely to have formal credit. Thus, the model reproduces most of the attributes of the relatively small selection of firms with formal credit.

\section{Conclusion}

Despite a period of reforms following the general election in 2010, Myanmar struggles with one of the World's most underdeveloped financial sectors. The insufficiency of credit is said to depress the growth of the manufacturing sector. Accordingly, it is important to both expand and improve the allocation of loanable funds for manufacturing firms. 
Using data from a new, nationally representative survey of SMEs in Myanmar in 2017 , we confirm the perceived scarcity of funds in the manufacturing sector. We estimate that only $8 \%$ of registered SMEs had formal debt and that approximately the same low fraction of firms (9\%) applied for a formal loan. We also show that many SMEs choose to self-select out of the formal credit market in Myanmar, even though they have documented credit demand. They simply choose not to apply for formal loans even if they have external financing needs, and those that do apply often have problems getting the loan. Thus, many firms are rationed, either by outright loan rejection, or because of overly complicated application procedures. Even the relatively few firms that got a loan without problems (142 out of a sample of 2237 SMEs) report that they were rationed as they could not get the funds they applied for.

Given this scarcity of formal credit, we examine if the existing funds are allocated towards firms with a higher growth potential as measured by the managerial capacity and personality traits of the firm manager. We show that entrepreneurial ability and risk behaviour is strongly associated with enterprise performance, and that better managerial capabilities are positively associated with the probability of applying for external financing. But conditional on applying for credit we find no relationship between being granted credit and the managerial capacity and personality traits of the firm manager. As such, we find no discernible association with the probability of obtaining a formal loan, conditional on revealed credit demand. Still, our results lend support to the hypothesis that capable managers in SMEs in developing countries have more productive firms in part because they are relatively better at easing liquidity constraints by getting formal credit. However, in Myanmar the better access to credit is mainly associated with a higher likelihood of actually applying for credit than with a higher probability be being granted credit, once they apply.

Our findings have obvious policy implications. Manufacturing sector growth in Myanmar could in all likelihood be enhanced — even with no or modest capital deepening - if the formal financial sector could reallocate available funds better towards enterprises with higher growth potential in the form of firms managed by more capable people. Along with general financial sector reforms, it would be beneficial if the banks get incentives to look for and fund (young) firms with good business and investment proposals that are run by high-capability managers. At the moment it appears that formal banks in Myanmar are forced to focus on high collateral requirements while they use quite limited information about firm managers in their assessment of loan applications. Promoting the use of assessments of managerial capabilities would be a relatively easy and cheap way of improving allocative efficiency in the formal financial markets in Myanmar. Such an initiative could be accompanied by training programmes for credit providers such that the information collected can be efficiently utilized, especially when allocating guaranteed loans among SMEs. As our findings also indicate that owners and managers with better managerial capacities may be better at overcoming obstacles related to applying for formal credit, an additional option is to offer training in business skills to owners and managers of SMEs in Myanmar. 


\section{Appendix: The Myanmar Enterprise Monitoring System (MEMS)}

The Myanmar Enterprise Monitoring System is an enterprise survey conducted in 2017 in all states and regions of Myanmar (MOPF 2018). To ensure representativeness at state/region level, manufacturing enterprise population data were established through collection of nationwide local municipal office data. Municipal office data include information from city development committees (CDCs) and development affairs organizations (DAOs), which provide business-operating licences and construction permits, and ensure water, sewerage, and trash collection services for firms. Moreover, they are often responsible for urban road maintenance and electricity, and they are the relevant tax-collection entities for property taxes. Licensing/registration at the municipal level is a legal requirement for all manufacturing businesses in Myanmar and, given that registration remains valid for only one year, municipal data lists are expected to provide an up-to-date picture of the population of registered firms in Myanmar.

The municipal lists have the following information about the firms: name, address and sector (MSIC four-digit codes). The sampling frame is restricted to the manufacturing sector (MSIC two-digit 10-33). Since 28\% of registered firms were listed as rice mills (MSIC sector 1063), the list of firms was stratified into (1) rice mills and (2) other manufacturing. To ensure representativeness at the state/region level for 'other manufacturing' firms, we first merged the lists for Chin State an Rakhine State and subsequently used the sample-to-population ratio for the state with the smallest number of registered enterprises. For budgetary reasons the sample size in the other states/regions was determined using a square root rule. Moreover, for reasons of implementation, the survey had to be restricted to a limited number of townships within each state/region. Firm selection was therefore done following a twostep procedure. In the first step, townships within each state/region were selected using probability proportional to size sampling. The number of selected townships in each state/region was determined proportionally to the number of townships in each state/region while the probability of selection was determined by the number of firms in each township relative to the number of firms in the state/region. As some townships in Rakhine and Shan were listed as so-called 'black' townships these were given a selection probability of zero. In the second step, firms within each selected township were randomly selected from the municipal list. Rice mills were sampled using the same sample-to-population ratio and square root rule within the selected townships (as described above) and sampling weights have been calculated.

As all data were gathered by face-to-face interviews with owners or managers of the firms, enumerators were asked to on-site identify firms not represented in the sampling frame but visually identifiable within the township. As such the non-registered firms were sampled through on-site 'block' identification of informal firms operating alongside the formal entities. Thus, while the group of listed firms represents the formal manufacturing sector, our sample of informal businesses is not representative of 'non-listed' manufacturing firms in Myanmar. They represent the more established and productive informal entities. 
Electronic supplementary material The online version of this article (https://doi.org/10.1057/s41287020-00318-4) contains supplementary material, which is available to authorized users.

Acknowledgements We are grateful for productive collaboration with the Central Statistical Organisation (CSO) in Myanmar and for research assistance provided by Paula Castro Rodriquez, Bjørn Bo Sørensen and Helge Zille. We are also grateful for insightful comments from two anonymous referees that greatly improved the paper. Apart from this, the usual caveats apply.

Open Access This article is licensed under a Creative Commons Attribution 4.0 International License, which permits use, sharing, adaptation, distribution and reproduction in any medium or format, as long as you give appropriate credit to the original author(s) and the source, provide a link to the Creative Commons licence, and indicate if changes were made. The images or other third party material in this article are included in the article's Creative Commons licence, unless indicated otherwise in a credit line to the material. If material is not included in the article's Creative Commons licence and your intended use is not permitted by statutory regulation or exceeds the permitted use, you will need to obtain permission directly from the copyright holder. To view a copy of this licence, visit http://creativecommons.org/licen ses/by/4.0/.

\section{References}

Annamalai, Nagavalli. 2017. Banking on Myanmar's financial sector: The road ahead Washington. Washington: World Bank Group.

Aterido, Reyes, Thorsten Beck, and Leonardo Iacovone. 2013. Access to finance in Sub-Saharan Africa: Is there a gender gap? World Development 47: 102-120. https://doi.org/10.1016/j.worlddev.2013. 02.013.

Ayyagari, Meghana, Asli Demirgüç-Kunt, and Vojislav Maksimovic. 2008. How important are financing constraints? The role of finance in the business environment. The World Bank Economic Review 22 (3): 483-516. https://doi.org/10.1093/wber/lhn018.

Bandiera, Oriana, Andrea Prat, Stephen Hansen, and Raffaella Sadun. 2017. CEO behavior and firm performance, Working Paper 23248, National Bureau of Economic Research. https://doi.org/10.3386/ w23248.

Banerjee, Abhijit, Dean Karlan, and Jonathan Zinman. 2015. Six randomized evaluations of microcredit: Introduction and further steps. American Economic Journal: Applied Economics 7 (1): 1-21. https:// doi.org/10.1257/app.20140287.

Beck, Thorsten, and Asli Demirgüç-Kunt. 2006. Small and medium-size enterprises: Access to finance as a growth constraint. Journal of Banking \& Finance 30 (11): 2931-2943. https://doi.org/10.1016/j. jbankfin.2006.05.009.

Bernhardt, Thomas, S. Giles Dickenson-Jones, and K. De. 2017. New kids on the ASEAN block: Myanmar SMEs and regional economic integration. Journal of Southeast Asian Economies 34 (1): 4-38.

Bigsten, Arne, Paul Collier, Stefan Dercon, Marcel Fafchamps, Bernard Gauthier, Jan Willem Gunning, Abena Oduro, Remco Oostendorp, Cathy Patillo, Måns Söderbom, Francis Teal, and Albert Zeufack. 2003. Credit constraints in manufacturing enterprises in africa. Journal of African Economies 12 (1): 104-125. https://doi.org/10.1093/jae/12.1.104.

Bloom, Nicholas, and John Van Reenen. 2007. Measuring and explaining management practices across firms and countries. The Quarterly Journal of Economics 122 (4): 1351-1408. https://doi.org/10. 1162/qjec.2007.122.4.1351.

Bloom, Nicholas, Raffaella Sadun, and John Van Reenen. 2016. Management as a technology?, Working Paper 22327, National Bureau of Economic Research. https://doi.org/10.3386/w22327..

Bruhn, Miriam, Dean Karlan, and Antoinette Schoar. 2018. The impact of consulting services on small and medium enterprises: Evidence from a randomized trial in Mexico. Journal of Political Economy 126 (2): 635-687. https://doi.org/10.1086/696154.

CDEB. 2018. SMEs loan and interest rate, Technical report, Central Department of Small and Medium Enterprises Development. http://www.smedevelopmentcenter.gov.mm. Accessed 18 July 2018. 
Chan Mya Htwe. 2017. Agricultural sector and SMEs to receive private bank loans. Myanmar Times. https://www.mmtimes.com/business/25141-agricultural-sectorand-smes-to-receive-private-bankloans.html. Accessed 18 July 2018.

Chassat, Philippe, and Florian Forster. 2016. Myanmar banking sector 2025: The way forward. Germany: Roland Berger GmbH.

Chaudhuri, Kausik, Subash Sasidharan, and Rajesh Seethamma Natarajan Raj. 2018. Gender, small firm ownership, and credit access: Some insights from India. Small Business Economics. https://doi.org/ 10.1007/s11187-018-0124-3.

Cowan, Kevin, Alejandro Drexler, and Álvaro Yañez. 2015. The effect of credit guarantees on credit availability and delinquency rates. Journal of Banking \& Finance 59: 98-110. https://doi.org/10. 1016/j.jbankfin.2015.04.024.

de Mel, Suresh, David McKenzie, and Christopher Woodruff. 2008. Returns to capital in microenterprises: Evidence from a field experiment. The Quarterly Journal of Economics 123 (4): 13291372. https://doi.org/10.1162/qjec.2008.123.4.1329.

Dohmen, Thomas, Armin Falk, David Huffman, Uwe Sunde, Jürgen Schupp, and Gert G. Wagner. 2011. Individual risk attitudes: Measurement, determinants, and behavioral consequences. Journal of the European Economic Association 9 (3): 522-550. https://doi.org/10.1111/j.1542-4774. 2011.01015.x.

Fafchamps, Marcel, and Woodruff Christopher. 2017. Identifying gazelles: Expert panels vs. surveys as a means to identify firms with rapid growth potential. The World Bank Economic Review 31 (3): 670-686. https://doi.org/10.1093/wber/lhw026.

Hansen, Henrik, and John Rand. 2014. Estimates of gender differences in firm's access to credit in sub-saharan africa. Economics Letters 123 (3): 374-377. https://doi.org/10.1016/j.econlet.2014. 04.001.

Htin Lynn Aung. 2018a. Accounts must be in order for SMEs to qualify for loans. Myanmar Times. https://www.mmtimes.com/news/accounts-must-be-order-smes-qualify-loans.html. Accessed 18 July 2018.

Htin Lynn Aung. 2018b. Myanmar takes small steps towards providing greater liquidity for SMEs. Myanmar Times. https://www.mmtimes.com/news/myanmar-takes-small-stepstowards- providing-greaterliquidity-smes.html. Accessed 18 July 2018.

Kapteyn, Arie, and Saw Htay Wah. 2016. Challenges to small and medium-size businesses in Myanmar: What are they and how do we know? Journal of Asian Economics 47: 1-22. https://doi.org/10. 1016/j.asieco.2016.08.004.

Kremer, Michael, Jean Lee, Jonathan Robinson, and Olga Rostapshova. 2013. Behavioral biases and firm behavior: Evidence from Kenyan retail shops. American Economic Review 103 (3): 362-68. https:// doi.org/10.1257/aer.103.3.362.

Kyaw, Myint. 2016. Paradigm shift of microfinance in Myanmar. In Collection of papers on my- anmar's financial sector, eds. Om Ki and San Thein. Bonn and Eschborn: GIZ. Chap. 18.

McKenzie, David, and Christopher Woodruff. 2017. Business practices in small firms in developing countries. Management Science 63 (9): 2967-2981. https://doi.org/10.1287/mnsc.2016.2492.

McKenzie, David J. and Dario, Sansone. 2017. Man vs. machine in predicting successful entrepreneurs: evidence from a business plan competition in Nigeria, Policy Research Working Paper Series 8271, The World Bank.

MOPF. 2018. Myanmar micro, small and medium enterprise survey survey 2017, Descriptive report, UNU-WIDER. https://www.wider.unu.edu/sites/default/files/Publications/Report/PDF/MyanmarMSMEsurvey- 2017.pdf. https://www.wider.unu.edu/sites/default/files/Publications/Report/PDF/ Myanmar-MSME-survey-2017.pdf.

Pattillo, Catherine, and Måns, Söderbom. 2000. Managerial risk attitudes and firm performance in ghanaian manufacturing: an empirical analysis based on experimental data, CSAE Working Paper Series 2000-17, Centre for the Study of African Economies, University of Oxford. https://ideas.repec. org/p/csa/wpaper/2000-17.html.

Quinn, Simon, and Woodruff Christopher. 2019. Experiments and entrepreneurship in developing countries. Annual Review of Economics 11 (1): 225-248.

Schellhase, John, and Lena Sun. 2017. The banking sector in Myanmar: An assessment of recent progress, Technical report. Santa Monica: Milken Institute.

Sharma, Smriti, and Finn Tarp. 2018. Does managerial personality matter? Evidence from firms in Vietnam. Journal of Economic Behavior \& Organization 150: 432-445. https://doi.org/10.1016/j.jebo. 2018.02.003. 
SMIDB. 2018. Small and medium industrial development bank, Myanmar. http://smidb.com.mm/page/ about-smid/3. Accessed 18 July 2018.

Thiha Ko Ko. 2018. JICA SME loans K60b in 2015-17. Myanmar Times. https://www.mmtimes.com/ news/jica-sme-loans-k60b-2015-17.html. Accessed 18 July 2018.

Tun, Ei Shwe Sin. 2016. Implementation of SME development law in Myanmar. In Collection of papers on myanmar's financial sector, eds. Om Ki and San Thein, 97-100. Bonn and Eschborn: GIZ. Chap. 16.

Vieider, Ferdinand M., Mathieu Lefebvre, Ranoua Bouchouicha, Thorsten Chmura, Rustamdjan Hakimov, Michal Krawczyk, and Peter Martinsson. 2015. Common components of risk and uncertainty attitudes across contexts and domains: Evidence from 30 countries. Journal of the European Economic Association 13 (3): 421-452. https://doi.org/10.1111/jeea.12102.

Waldschmidt, Sophie, and Marga, Scheck. 2016. The views of Myanmar bankers on the progress of domestic SME finance. In Collection of papers on myanmar's financial sector, eds. Om Ki and San Thein, 76-81. Bonn and Eschborn: GIZ. Chap. 12.

Win, Sandar. 2018. Banks' lending behaviour under repressed financial regulatory environment: In the context of myanmar. Pacific Accounting Review 30 (1): 20-34. https://doi.org/10.1108/ PAR-05-2016-0054.

World Bank. 2015. Myanmar economic monitor: Staying the course on economic reforms. Washington: World Bank Group.

World Bank. 2018. Doing business 2018: Reforming to create jobs. Washington: World Bank Group.

Publisher's Note Springer Nature remains neutral with regard to jurisdictional claims in published maps and institutional affiliations. 